\title{
Geological Effect on the Grlište Reservoir Water Quality
}

\section{Zoran Nikić', Milka Vidović ${ }^{2}$, Milica Nadeždićc ${ }^{3}$, Boban Milovanović ${ }^{4}$}

\section{Abstract}

This work presents analytical data for copper (Cu), zinc ( $\mathrm{Zn})$ and manganese $(\mathrm{Mn})$ of the Grlište storage reservoir that was built for water supply to Zaječar and the nearby communities. Because there was not any industry of military work that could be a source of heavy metals, the research focused on the geology of the area drained to the impounded lake. Occurrences and deposits of minerals in the area were registered and concentrations of copper, zinc and manganese in the lake analysed and graphically represented. Water samples the analyses were taken at the upstream and downstream ends and the middle of the lake, each from three depths: lake surface, mid-depth and near the floor. Measurements spanned the period from 1991 to 2004. The copper and zinc concentrations had a gently rising trend in all sections, and manganese only in the upstream end of the lake.

Key words: artificial lake, water supply, geology, heavy metals, Grlište.

Faculty of Forestry, University of Belgrade, Kneza Višeslava, 11030 Belgrade, Serbia

${ }^{2}$ Institut of Chemistry, Technology and Metallurgy, University of Belgrade Negoševa 12, 11000 Belgrade, Serbia

3 Republic Hydrometeorological Institute, 66 Kneza Viseslava, 11030 Belgrade, Serbia

${ }^{4}$ Galenika a.d., Batajnički drum bb, 11080 Zemun, Serbia

\section{Introduction}

A dam was constructed in 1990 on the Grlištka river, eastern Serbia, to impound water for supply to Zaječar and the nearby local communities. The Grliška river, formed by the confluence of the Lasovačka and Lenovačka rivers at the northern foothills of Tupižnica mountain (Fig. 1), is a left tributary to the Beli Timok. Its catchment to the Grlište reservoir has an area of $181 \mathrm{~km}^{2}$ The dam is a rockfill embankment with the $\mathrm{u} / \mathrm{s}$ face of reinforced concrete, $101.3 \mathrm{~m}$ long at the crest and $27 \mathrm{~m}$ high. The lake volume at the maximum backwater level is $10.9 \times 10^{6}$ $\mathrm{m}^{3}$, its surface about 250 ha and the average depth $6 \mathrm{~m}$ (Tabački et al., 1992).

There are no industrial, tourist or military works in the catchment, except two metallic and one energy-producing mineral mines that were worked until the late sixties. Metallic mineral occurrences are registered in several places (Veselinović et al., 1967) of a part of the catchment area.

Different materials carried from the catchment began depositing in the reser- voir from its formation. The good quality of flowing water that is impounded does not necessarily mean the same quality of the lake water (Nikić, 1994). Besides the physical reduction of the useful storage volume, sediments enhance numerous chemical and biological processes that affect the quality of lake water. The problem is even more complicated by the presence of deposits or occurrences of metallic minerals in the topographic or hydrologic drainage area (Nikić et al., 2006). Concentrations of copper, zinc and manganese in the Grlište Lake were measures from 1991 to 2004. Also, metallic mineral deposits in the catchment area were considered. Interpretations of the results are a basis for the conclusions and recommendations given in section 5 of this work.

\section{Materials and method}

The Republic Hydrometeorological Institute of Serbia has monitored water quality in Grlište Reservoir since 1991 under the legislation that have bearing on systemat-

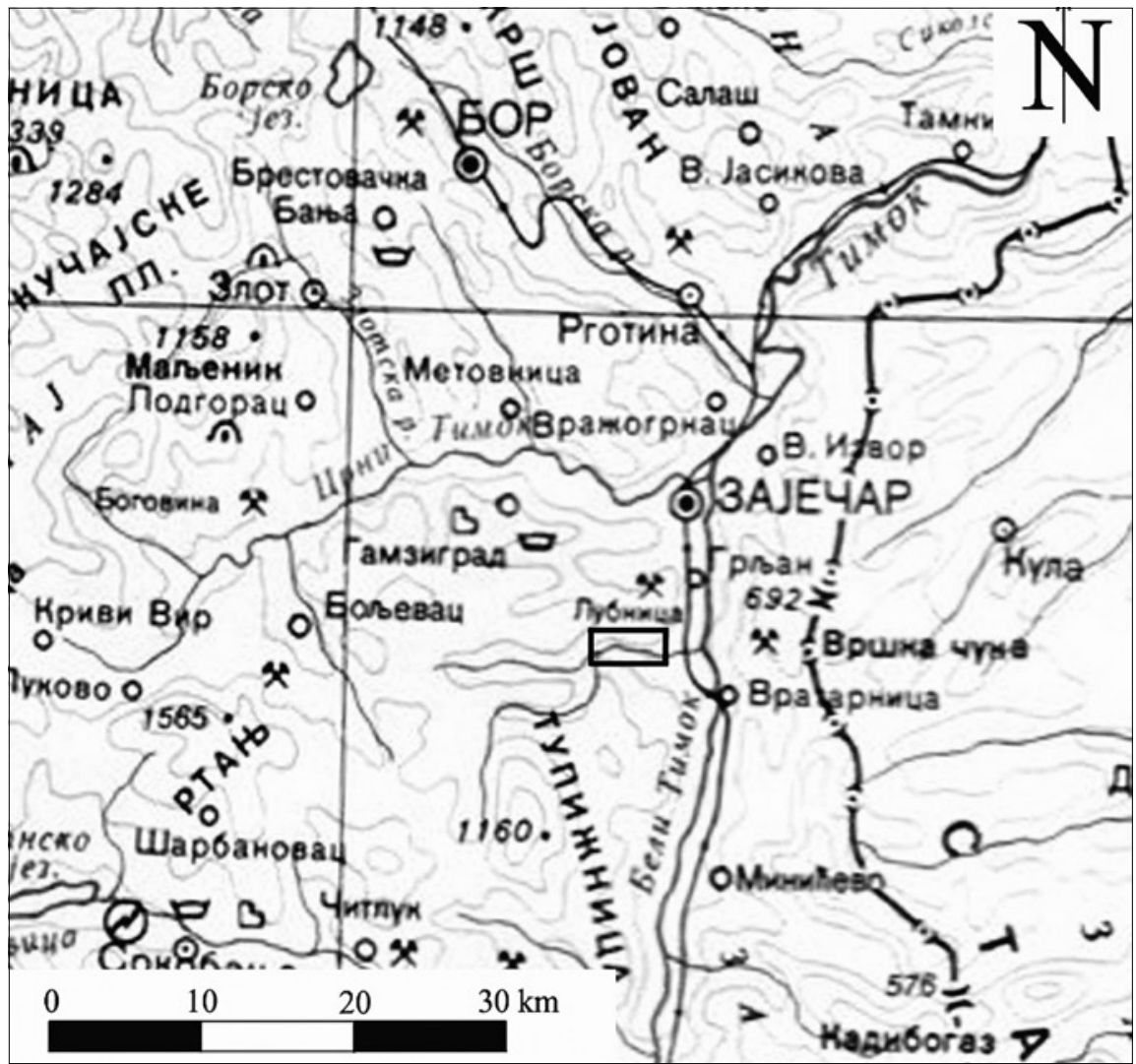

Figure 1 Physical setting of the Grlište Reservoir. 
ic water testing passed by the Serbian Government (Water Law, 1994). The monitoring information is published in the form of Hydrological Yearbook, 3. Water Quality (Collective authorship, 1991-2004).

Water from the Grlište Lake was sampled for physical and chemical analyses in three sections: at the dam (A), middle of the lake (B) and upstream end of the lake (C), from three depths: surface (1), middepth (2) and at the floor (3) (Fig. 2). The lake depths were from $20 \mathrm{~m}$ to $22 \mathrm{~m}$ at the dam, from $11 \mathrm{~m}$ to $14 \mathrm{~m}$ in the mid-length and from $3 \mathrm{~m}$ to $4 \mathrm{~m}$ at the upstream end.

Water quality in the lake was serial tested (1991-2004) mostly in the summer (June-October), excluding 1999 and to a reduced volume (only for $\mathrm{A}_{1}, \mathrm{~A}_{2}, \mathrm{~A}_{3}$ and $\mathrm{C} 1)$ in 2000 and 2001 for the known reason. Concentrations of heavy metals dissolved in water were determined by standard analytical procedures (APHA), 1995). A statistical analysis could not exactly depict the situation in the aquatic system of the lake, but statistical processing of data was one of the modes to present and analyse exactly the water quality change.

On the basis of the available published information, geology of the catchment area, mineral occurrences and deposits are studied and the area and the old mine workings reconnaissance surveyed (Nikić, 1998). Analytical results for copper, manganese and zinc concentrations in Grlište lake water are classified by sampling places and sections. Because the tabulated statistical data do not indicate the distribution and change of water quality in time, these variations in the considered parameters are illustrated on Figures 3, 4 and 5.

\section{Results and discussion}

\section{a) Mineral deposits and occurrences in the catchment}

The types of ore minerals and their location in the catchment are represented on the basis of the available documentation, Explanatory Text for the BGM 1:100,000 Sheet Zaječar and the reconnaissance survey. Several occurrences of different metallic, energy-producing and non-metallic minerals are registered in the Grlište catchment area. Metallic minerals are copper, iron and manganese, and the energy-producing mineral is coal. Occurrences of metallic minerals are related to the Timok Andesite Massif extending west of Tupižnica mountain.

Copper is registered in several locations. With respect to paragenesis of the identified minerals and their modes of occurrence, the mineral deposits are divided into two formations. One is characterized by higher copper in the Vrbovačka river source area (Fig. 3) at Markov Kamen and a location upstream of Bačevica

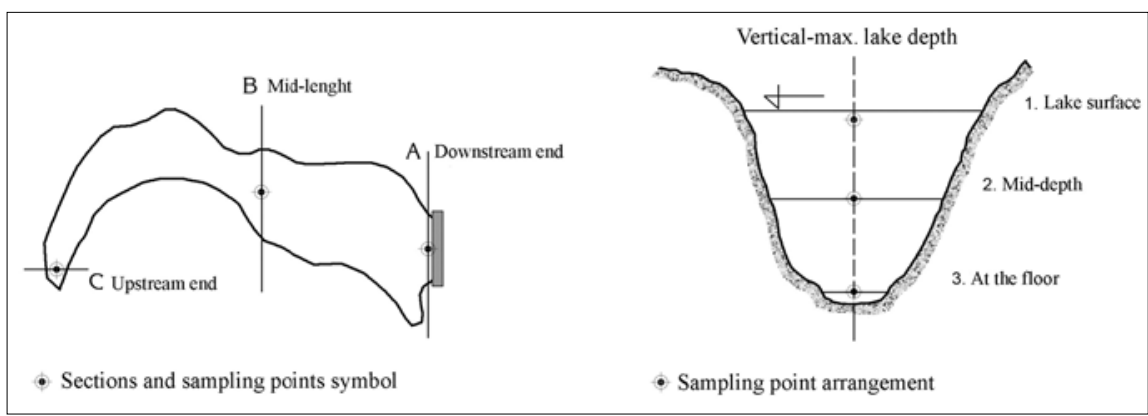

Figure 2 Sketch figure of sections, sampling places and their identification numbers for Grlište storage reservoir.

in the Bačevička river basin where copper and iron were worked. The accessory minerals are associations of minerals: covellite $(\mathrm{CuS})$, chalcocite $\left(\mathrm{Cu}_{2} \mathrm{~S}\right)$, bornite $\left(\mathrm{Cu}_{5} \mathrm{FeS}_{4}\right)$ and chalcopyrite $\left(\mathrm{CuFeS}_{2}\right)$. The other formation is characterized by lower

copper and accessory minerals, registered in the following locations: Mečiji Vis in the Lasovačka river source area, Šumlatica in the Bačevička river basin, Bukova Glava in the Lasovačka river basin, the Bačevička river and the Ježevica source area and the

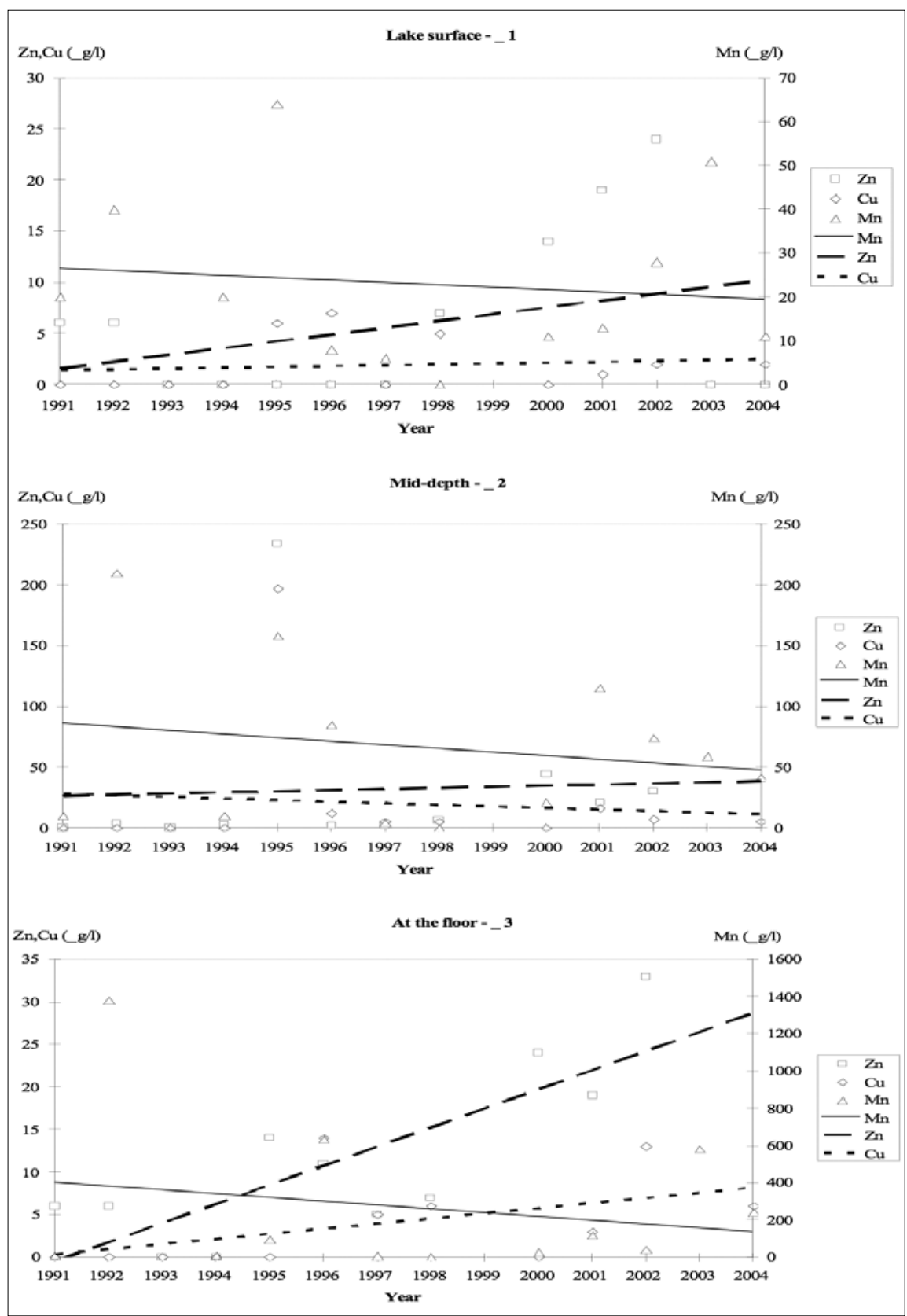

Figure 3 Copper, zinc and manganese concentrations in Grlište reservoir at the dam $(A)$ : at surface $\left(A_{1}\right)$, mid-depth $\left(A_{2}\right)$ and at the floor $\left(A_{3}\right)$. 


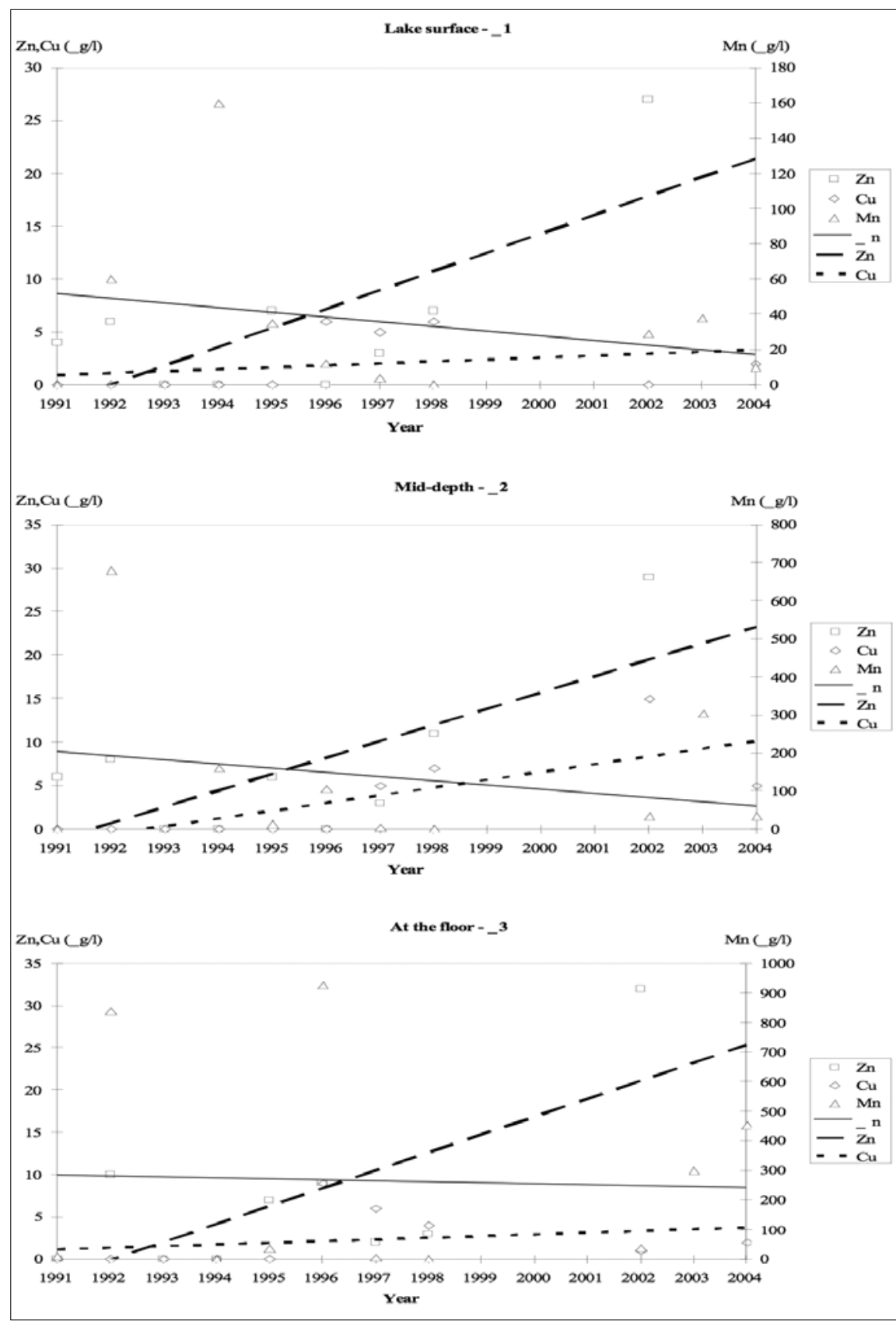

Figure 4 Copper, zinc and manganese concentrations in Grlište reservoir in the lake mid-length (B): at surface (B1), mid-depth (B2) and at the floor (B3).

Banosavička river source area. All these mineral occurrences fall into the group of sulphite mineral deposits (Veselinović et al., 1967). Manganese occurrence within an andesite massif is registered near Lasovo in the Lasovička river basin. This mineral forms veins filling fissures in andesite breccia. Two examined mineral samples contained manganese $22.85 \%$ and $36.75 \%$. The sample with the lower manganese content also contained $\mathrm{Fe} 0.78 \%, \mathrm{Cu}$ $0.12 \%, \mathrm{SiO}_{2} 29.30 \% \mathrm{Au} 0.3 \mathrm{~g} / \mathrm{t}$ and $\mathrm{Ag} 0.90$ $\mathrm{g} / \mathrm{t}$ (Veselinović et al., 1967).

Of the energy-producing minerals a lignite deposit is recognized. Lignite was worked in a location north of Lenovac in the Lenovačka river basin. This occurrence is associated with Miocene deposits.

Rock masses, including minerals, which build up the catchment area, are destruct- ed by erosion, specifically chemical decomposition and physical disintegration. Under favourable geological, hydrogeological and geomorphologic conditions the produced solutions and rock waste move and reach streams (Nikić, 1996). Water flows from the ground surface through fractures and faults dissolving rock and mineral materials on its way. The order of element solvency, or the element migration ability is controlled by the ionic valence (Shvartsev, 1982). Streams into the storage reservoir carry weathered material prepared for transportation.

Rock erosion, waste transportation and filling and its accumulation in the basin are one of essential natural processes that is affecting the quality of lake water over the time as compared with freely flowing water before the dam was constructed (Nikić, 1997). b) Copper, zinc and manganese concentrations in Grlište Lake water

The manganese, copper and zinc concentrations and variations over the period 1991-2004 are shown in diagrams 1, 2 and 3 for three depth points in three lake sections. Diagram 1 shows the three elements variations in three points of section (A) at the dam, diagram 2 for section (B) in the lake mid-length and diagram 3 for the $\mathrm{u} / \mathrm{s}$ lake-end section (C).

The concentration of copper dissolved in the Grlište reservoir evidently increased over the study period in each sampling point, except $A_{1}$ and $A_{2}$. It was unchanged in $A_{1}$ (lake surface) and decreased in $A_{2}$ (mid-depth). Given the registered copper occurrences and deposits in the lake catchment, the increasing trend in dissolved copper concentration is expected to continue.

The rise of dissolved zinc concentration in Grlište Reservoir is notable in all sampling sections and depths.

Manganese concentration shows a decreasing trend in all sampling points of sections $\mathrm{A}$ and $\mathrm{B}$, but it rises in all three points of section $C$. The trend may change with the time in sections $\mathrm{A}$ and $\mathrm{B}$, given the manganese mineral occurrences in the catchment area.

\section{Summary}

Grlište Dam was built to impound water for supply to Zaječar and nearby communities. Geology of the area drained into the storage reservoir includes deposits and occurrences of different minerals that characterize it. Variation trends of copper, manganese and zinc concentrations in water of Grlište Reservoir, monitored from 1991 to 2004 in three lake sections at three depths, indicates the following:

- Notable rise in zinc concentration in all three sections and three depths;

- Increased copper concentration in three sections and depths, except A1 where it is unchanged and A2 where it is decreased;

- Manganese concentration decrease in sections $A$ and $B$, and increase in $C$ through the depth.

The inference from the obtained data is that geology of the Grlište catchment influences chemical composition of the lake water. Any prediction of the future quality of water, based on the present trend in manganese, copper and zinc concentrations would be tricky. It should be preceded by detailed geological exploration in the area built up of volcanogenic-sedimentary rocks for possible identification of the yet unregistered heavy mineral occurrences. In the meantime, some of the numerous preventive measures should be urgently 
taken to restrict or lessen the mineral contaminating effect on the lake water.

\section{Acknowledgement}

This work was executed under the basic research programme, Project 146021B: Geological and ecotoxicological research in the identification of geopathogenic zones of toxic elements and natural radioactivity in storage reservoirs for domestic water supply in the Republic of Serbia, funded by the Ministry of Science of the Serbian Government.

\section{References}

APHA, AWWA, WPCF, 1995. Standard Methods for Examination of Water \& Wastewater (19th Ed.) APHA, AWWA,WPCF.

Veselinović, M., Antonijević, I., Lončarević, Č., Kalenić, M., Rajčević, D., Krstić, B., Banković, V., Rakić, B. 1967. BGM 1:10o,ooo Sheet Zaječar and Textual Explanation. Federal Geological Institute, Belgrade.

Tabački, Z., Vukčević, N. 1992. History of the Grlište Reservoir Drainage Area and a Part of Tupižnica Mountain Range. Book 3. Natural Character of the Project Area. PKB Agroengineering Co, Belgrade.

Collective authorship, 1992-2004. Hydrologic Yearbook. 3. Water Quality. Republic Hydrometeorological Institute, Belgrade.

Nikić, Z. 1998. Influence of Artificial Surface Reservoirs on Geology. Zaštita prirode 48-49, 223-232.

Nikić, Z. 1997. A Contribution to the Methodology of Hydrogeological Studies for Water Quality Prediction and Maintenance in Surface Storage Reservoirs. Symposium: 100 Years of Hydrogeology in Yugoslavia, Proceedings, Belgrade, pp. 227-233.

Nikić, Z. 1996. Water Quality in Artificial Surface Reservoirs Affected by Local Geology. Water Protection '95 Conference, Proceedings, Ulcinj, pp. 422-427.

Nikić, Z. 1994. Importance of Hydrogeological and Geological Data Base for the Understanding and QualityMaintenance of Water in Surface Reservoirs Intended for Water Supply. 1oth Yugoslav Symposium on Hydrogeology and

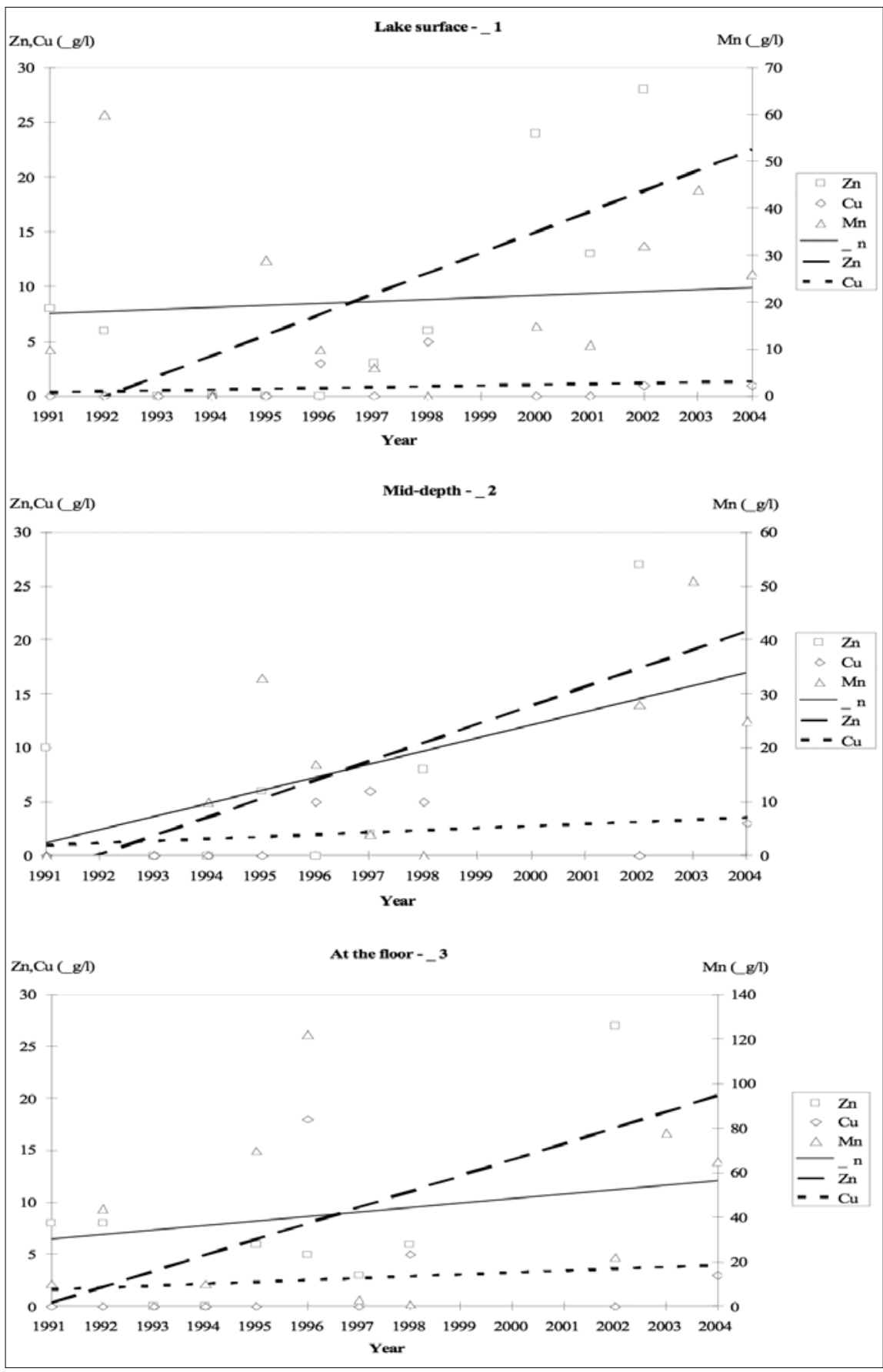

Figure 5 Copper, zinc and manganese concentrations in Grlište Reservoir at $\mathrm{u} / \mathrm{s}$ end (C): at surface $\left(\mathrm{C}_{1}\right)$, mid-depth $\left(\mathrm{C}_{2}\right)$ and at the floor $\left(\mathrm{C}_{3}\right)$.

Engineering Geology, Proceedings, Kikinda, pp. 143-146.

Nikić, Z., Vidović, M., Nadeždić, M. 2006. Grlište Catchment Geology Risk to the Quality of Lake Water. Water 2006. Proceedings. Yugoslavian Society for
Water Protection, Zlatibor, pp. 379384 .

Shvartsev, S.L., 1982. Hydrogeochemistry. Siberian Division, Novosibirsk.

Water Law. Official Gazette of R.S., br. 46/91, 53/93, 67/93 i 48/94. 